\section{Summary}

I believe we have much to be proud of in the Canadian forest industry. And it is the difficult times like the past three years that bring out the best in all of us.

Our environmental performance is as good as the best in the world and we stand ready to be measured by common standards of performance in the forests, in our mills, and in our use of recycled fibre.

Our products are clean, safe, biodegradable and re-useable or recyclable. The natural forest resource on which the industry is based is renewable and, at least in Canada, is fully renewed.

Forest products improve the quality of life of everyone on this planet. They provide heat, shelter and an incomparable medium for communications, for protective packaging and for sanitary purposes.

And finally world demand for the products of our industry will continue to grow... both in traditional markets, in newly emerging countries and countries in transition to market based systems.

This increased demand will provide a basis for new investment, new jobs and increased generation of wealth for the Canadian economy to the benefit of all Canadians.

All we ask for is a favourable climate for doing business. We need a working partnership with government, not to get subsidies, but to ensure that our basic costs for access to fibre, energy and capital are not out of line with our competitors abroad, and we need government to work hard to negotiate secure and free access to the US and other foreign markets.

We need to work more closely with both government and labour to ensure that we have the right skills in the workplace and that work rules as well as pay and benefits provide a basis for mutual growth and prosperity for all of us.

The potential of the Canadian forest industry is constrained only by the limits of sustainable and wise use of our forest resources.

Our reward will always be to provide a better quality of life for all Canadians. Imagine a world without wood! Imagine a world without books! Imagine a world without paper!

\title{
Valorization, Deregulation and Privatisation of Forests for Dynamic 21st Century Forestry
}

\author{
by Jacques J. Gauthier \\ Consultant, Portneuf Station, Québec
}

\section{Introduction}

At no time in the history of mankind has forestry received so much attention as in recent years. Factors that have contributed to drawing the attention of politicians, planners and the media to the vital importance of forests for the well-being of people are: world-wide environmental degradation, the shrinking of forest areas in industrialized countries and in the tropical forests of developing countries, perceived climate changes, the extinction of species, and more recently, the economic recession.

The consequences of this awakening to forestry have been deep and troubling for the profession, for governments, for industry and for those who earn their living from forests.

While foresters were trying to modify industrial forestry to make it socially acceptable and lasting, they were bypassed by the environmental movement. It succeeded in creating a split between "participatory" or "environmental forestry" and industrial forestry. Many foresters reacted by retreating into a posture of defending their convictions or, even worse, lost confidence in themselves and in their profession. They saw themselves as powerless to reverse the movement and did not feel prepared to practise the new forestry that was being imposed on them. For some foresters as well as for many others, forestry had become too important to be left to foresters.

Faced with this situation, it became acceptable and even noble for governments to direct larger and larger sums to environmental or social forestry projects, and almost unacceptable to adequately support industrial forestry. Canadian forests, like those in Québec, thus became an expense item for governments, whereas until recently they were a net source of revenue. In order to justify deficit bud- gets because of falling direct revenues, and to provide subsidies that were out of context with the economy, elected officials ended up taxing forestry revenues generated by corporations and individuals. It is surprising that in these circumstances we still dare to classify the forests as a natural resource of our country.

Private forests, those that are the most accessible and productive, are no longer able to sell all of their wood, and are only profitable because of the government subsidies they receive. In managing their private woodlots, owners have become welfare recipients.

The forest industry, which generates the necessary funds to manage our forests, is evolving in a more and more competitive international market. The industry is heavily regulated by the provinces and is subject to constant interference by governments, as much at the regulatory level as in manufacturing itself. It is becoming more and more difficult for our industries to stay profitable while satisfying the market demands for quality, environmental standards imposed by both importing countries and our own governments, and the need to adapt quickly and continuously to new conditions.

People who gain their livelihood from the forest are used to government interference in the forestry sector. Faced with the hopelessness of their situation, they use the only means available to them that still seem effective in getting action civil disobedience. The consequences are even more interference by governments, which undermines industry's competitive position even more, breaks the delicate balance of the competitive system and chases away potential investors.

Paper presented at the Wrap-up Plenary Session, 1993 Annual Meeting. 
This is the context within which we find ourselves as we move towards 21 st century forestry. I dare to hope that as foresters we will demonstrate our expertise in a dynamic and convincing way, so that the new forestry will be shaped by factors other than those coming from outside the sphere of forestry professionals.

\section{International Context}

We must look at forest management and development in a global context. We are faced by global and international environmental problems which can be solved in part by forestry. It would reflect badly on us if we didn't take them into account in our management decisions. On a world scale, however, both mankind and industry have again become nomads. Based on democratic principles and a market economy, they go where food and wealth are easier to obtain by work or investment. We owe it to ourselves to create a climate in our country which allows our forest industries to progress so they can attract industry and manpower.

The type of forestry which is evolving and toward which we are working for our country must therefore be based on the global context. It will take into account both demographic changes and the impact it causes on the environment and on the economy.

\section{Demographic Context}

Even though our understanding of the relationship between population, poverty, resources and the environment is incomplete, it is nevertheless clear that overpopulation leads to poverty. In turn, poverty leads to the squandering of resources, and economic development cannot take place when resources are depleted.

In tropical countries, poverty caused by population growth favours the urbanization of rural populations. Those who stay behind must clear the forest in order to satisfy their need for land to produce food. This situation triggers a chain reaction whereby cities, which are usually located on the best farmland, use up the best land in the country. This forces the rural people to farm increasingly large areas of marginal land which is often covered by forests. It is believed that two consequences of poverty, the growth of cities and the resultant search for agricultural lands, are responsible for 80 per cent of the loss of forest cover in tropical countries.

The role of population growth is increasing. In one century, from 1830 to 1930 , the population of the world increased by 1 billion. However, during the forthcoming decade, or $1 / 10$ the time, the world's population will also increase by 1 billion. It will reach 8.5 billion in 2025 .

In 1950, industrialized countries accounted for 32 per cent of the world's population. Because of a growth rate that has been three times lower than developing countries, they will account for only 15 per cent of the world's population in 2025. This explains why 94 per cent of the world's current population growth is in developing countries. The largest increases are taking place in the poorest countries, which have the highest rates of illiteracy.

At all levels of development, an increase in the population results in an increase in energy consumption, resources and environmental stress. The continuous and rapid population growth in developing countries puts the population growth curve on a collision course with available resources, and inevitably will result in increased poverty.

This is why in most industrialized countries the forested area is increasing in size, and will continue to do so, whereas in developing countries forests are disappearing at an alarming rate.

At the world scale it is imperative that development strategies be designed to balance population levels with the availability of resources, and that our standard of living take into account the earth's capacity to absorb man-made disturbances. Only then will sustainable development and protection of resources be possible.

All of this means that the immense problem of the disappearance of tropical forests and the resultant repercussions on the environment are caused by factors beyond the forest. Though the forests and foresters in Canada and throughout the world can make a contribution towards the solution of these environmental problems, they can not be expected to solve them on their own.

\section{Commercial Context}

The preceding facts concerning the evolution of the world's population have more than environmental repercussions. They also have an economic impact, as well as on the trade of forest products. Though it was not foreseen a few decades ago, poor countries were and will remain for some time, very low consumers of finished forest products. They use firewood and forest lands, which they employ for other purposes. Poverty prevents them from becoming large consumers of the forest products from industrialized countries. The forest industry should therefore not count on much more than a very small increase in the number of those who can ensure its continued growth - people who can afford their products.

In the affluent world of industrialized countries, change is rapid and competition is fierce. It is surprising to see how, in the space of a few decades, world forest resources and trade in forest products have changed. The former USSR, which encompassed almost a quarter of the world's forests, is for all practical purposes out of the export market because of an inability to harvest its forests and manufacture finished products. Countries in North America and Scandinavia have attained their maximum sustained yield harvest level. Because of plantations established after World War II, Japan has become the country with the highest proportion of forested area in the world, and France has become self-sufficient in wood. The new forest powers - New Zealand, Australia and Chile, are now becoming serious competitors for the gamut of exported forest products, both manufactured products and roundwood.

The minimal growth of the world's affluent population, the increase in forested areas in industrialized countries, and the substitution of forest products by other more economical ones, means that there will not be a global shortage of wood or forest products. Our whole society foresters, governments and citizens, must take responsibility for the forest industry. We must help it to compete if we want to remain competitive in the world trade of forest products, make our contribution to Canadian's 
standard of living and continue to enjoy the economic benefits flowing from our forests.

During the past few years, forest products producers in countries with high environmental standards have become worried about the impact of these regulations on their competitiveness. In Sweden, for example, big investments were made in paper mills during the 1980 s to control pollution. By the end of the decade industry found itself having problems with the competitiveness of its products. To overcome the problem, they began what was a more or less official campaign to make their main competitors, including Canada, adopt similar standards. Sweden was successful enough that it regained a strategic trade position.

Canada, having raised its standards to Swedish levels and experienced the resulting higher production costs, has to make almost impossible efforts to avoid losing its markets to countries with weaker environmental regulations. A good example is Chile, where the problem of under-development is taken advantage of to avoid dealing with environmental concerns. Their industrial forestry infrastructure is thus being quickly developed, based on some of the most beautiful and productive plantations in the world, and by rapidly harvesting and replacing their degraded natural forest.

In a context of abundance, it must be remembered that wood and wood products are commodities that are very sensitive to cost fluctuations. We are in a global forest products trade context, where the future will belong to those who have surplus resources available at a competitive price. We are among the fortunate ones who have the resource. If we want to continue to be one of the major players in the forest products trade, we must carefully weigh our forest management decisions and environmental policies to ensure that our products stay competitive.

\section{The National Context}

Canadian foresters must accept much of the blame for what is going wrong in forestry in Canada. The corollary, however, is that they can take credit for the country's important forestry successes.
Canada is fortunate to have 11 per cent of the forested area of the world and 7 per cent of the standing volume. From this resource we produce 10 per cent of the world's industrial wood. Also, Canada is the largest producer of newsprint in the world (29 per cent), second largest producer of wood pulp and softwood lumber (15 per cent each), and is also the world's largest exporter of all these products.

Canadian forests provide jobs to 900,000 people, supply $\$ 9.6$ billion in annual revenues and contribute almost $\$ 20$ billion annually to the country's balance of payments.

It is estimated that in Canada $\$ 3.7$ billion in government revenues come from forestry-related activities. However, it is important to note that more than 75 per cent of these revenues comes from taxes: 60 per cent from the personal income taxes of industry employees and 15 per cent from corporate taxes.

Because of the national success story that forestry has been, and in spite of our present difficulties, we owe it to ourselves to regain confidence in our profession. We must do so in order to continue contributing to the success of our industry and to the well-being of our citizens.

\section{The Québec Context}

Québec accounts for 20 per cent of the forested area and 19 per cent of the standing volumes in Canada, and therefore plays an important role on the world's forestry chessboard. It is the third largest producer of newsprint worldwide, and taken alone, is the second largest exporter after Canada as a whole. It makes up 20 per cent of forest products exports in Canada.

We have a tendency to forget that the forest industry is extremely important to Québec's economy. It contributes more than 7 per cent of all jobs, produces $\$ 13$ billion worth of goods annually, and exports $\$ 5$ billion worth of forest products and creates a favourable trade balance of $\$ 4.5$ billion per year. Forestry accounts for a large part of a Quebecer's high living standard.

The techniques and equipment that placed Canada at the top of world forestry productivity for harvesting small trees and sawing small-dimension logs were either adapted or invented in Québec. We have had some great forestry successes, but on the other side, our forests are not as productive as they should be, nor have we been able to make use of the 12 million $\mathrm{m}^{3}$ of hardwoods that are available annually.

Moreover, though we count on and are proud of our forest industry, it is going through apprehensive and difficult times. Wrestling with the necessity of renewing its production facilities, it is also facing a growing environmental thrust from provincial and federal authorities, who are forcing it to make large investments at a time when the recession is making access to capital difficult. In relation to its most important export market, the United States, recycled paper and the related requirements of American legislation are handicaps to the Québec industry's competitiveness. By forcing Canadian mills to use their recycled paper, the Americans have passed on part of their garbage treatment costs to Canada. They found a market for the paper that their environmental standards forced them to recuperate, and simultaneously rid themselves of the pollutants associated with de-inking. They have thus handed over to our industry a large number of their problems, including the significant increase in the cost of producing a tonne of newsprint.

It is sometimes helpful to ponder on our successes to cheer ourselves up. However, we foresters do not only have successes to boast about. We have often been responsible for the rape of our forests and guilty of useless manipulation of our forest systems. A large part of the province's commercial forest area is now covered with low quality forests, and we are making a third attempt at a provincial forest management regime.

The first regime used a quasi-global management system for areas controlled by licence holders of forest concessions. This regime, which had many good points, also had certain shortcomings. It allowed white pine and good quality oak to disappear. It slowed the development of the sawmill industry which had to go through the pulp and paper companies to get access to wood supplies. Companies were not always cooperative with the sawmills, but they con- 
trolled the concessions. Hunting and fishing rights, and the use of forested lands for these ends were difficult to manage under this type of regime.

The 1970 s was the period when government control was in fashion; rather than simply correct the trajectory of the previous system, everything was torn down to change the regime, supposedly to favour better forest management. At great cost to the province, forest concessions were revoked and all available seigneury lands were purchased, by invoking the need to manage Québec forests for the benefit of all the regions. This was the era when everything had to belong to the Province in order to be well managed. At that time there was even talk of passing a very restrictive law directed at private woodlot owners. However, in all honesty, this regime benefited the private sawmill industry by allowing it to develop, and many regional entrepreneurs emerged. However, it was very costly, and signalled the end of forest management in Québec. It even went so far as to abandon sustained yield harvesting of our forests.

We are now in a third forestry regime, which has also brought upheaval with it, but which has corrected several weaknesses of the preceding regime. It has reinstated the idea of sustained yield, and contributed to the rebirth of silviculture. On the other hand, it has already greatly favoured the integration of the sawmill industry with pulp and paper production. This has reduced competition in the forest supply system and caused the disappearance of a number of Québec's forestry businesses which the regions require for development. Finally, it has reduced the private woodlot owner to the level of a forest welfare recipient, with no market for his products. It is a costly system for the province, since funds are spent directly on forest regeneration, or industry projects are financed by using part of provincial stumpage fees, thus resulting in lost opportunities. Far from being efficient, it is vulnerable because of its high cost at a time when the province has a great need for funds elsewhere in the system. Therefore, this regime should be critically examined over the next few years.

\section{Valorization, Deregulation and Privatisation in the Service of People Who Make Their Living from the Forest}

This time, let's get it right by learning the lessons of the past, and gradually attack the restraints affecting forest development rather than the symptoms. What a great opportunity exists to revalorize forests, reinforce the competitive position of the industry, encourage the development of the communities who depend on forests and to set up a true partnership with the public to manage this important natural resource.

World events of the past few years have shown that as well as the need for democracy, we need a market economy and the privatization of the means of production. We have become aware of the need for strong governments that can ensure a smoothly running market economy while avoiding social injustices. To ensure the development of forestry, the role of government should be limited to ensuring a fair society, especially concerning the poorest and the unemployed, environmental protection, setting resource prices and administering efficient fiscal and taxation policies.

The adjustment of our present forestry regime to current and expected conditions should be accomplished in an incremental way, first with a considerable increase in stumpage fees on Crown lands. This would bring in enough revenues to allow for economic and profitable management of the resource. As a second step, which can be done concurrently, forestry and the forest industry need to be deregulated to allow them to evolve and to progress. Finally, the means of production, and in particular, a large proportion of the forests themselves should be privatized.

By keeping Crown stumpage fees at a low level, it would appear that industrial development was encouraged. This notion held true up to the 1960 s, but is no longer true because of the present context of full use of our forests. Since that time the low stumpage fees have resulted in a reduction of the value of Québec's forests. This is because, in any case, a large part of them returns to the industry in the form of grants of all types. Another byproduct of the low stumpage fee policy was to devalue the private woodlot sector, which is in direct competition with Crown forests, whether we admit it or not. Industry was spoiled by the low stumpage fee policy and by being given grants for construction, reconstruction, technological changes, pollution control, etc. Also, private woodlot owners were appeased and compensated for their loss of income through subsidies for forest management, land tax rebates, the Arsenault law (no longer in force) and by a "Rand" formula that favoured the Wood Producer's Office.

The system of direct taxation now in force has no relation to the economic value of the wood, nor with the merchantable value of standing timber. The end result is to convince industry that the resource is of little value. Consequently, any effort they make to manage it constitutes an expense rather than an investment. This policy has transformed the Ministry of Forests from a respected and profitable ministry into a deficit condition. It has made the private woodlot owner a welfare case. Finally, it has permitted the establishment of an inadequate silviculture system because it is based on subsidies. It was the brainchild of a provincial cabinet, which based the policy on government standards designed for ease of enforcement, rather than on local needs, professionalism of the private sector, or of regional governments.

Higher stumpage fees on Crown lands would reflect the forest's economic worth and would rehabilitate it as a renewable resource. It would also permit us to put into place a silviculture system which would be implemented without the need for coercive regulations or prompting measures, because it would be economically profitable. Last, we could abandon private woodlot subsidies and return to a silviculture based on the needs of existing forests and the market. It would be a great way to get large sectors of the public involved. Foresters could apply their expertise, rather than blindly carry out ministry directives that are not always correct. The 120,000 owners of private woodlots of their workers would graduate from the ranks of the welfare roles to being 


\section{ANNUAL MEETING POSTERS}

Planting eastern white pine with alder: A promising technique. Jean Beaulieu, Gaétan Daoust and Ariane Plourde, Forestry Canada, Québec Region.

PICEA - Program for interactive classification and estimation of areas. Jacques Bélanger, Faculté de foresterie et de géomatique, Université Laval.

Industrial chair in geomatics applied to forestry. JeanMarie Bilodeau, ing.f., M.Sc., Christopher Gold, Geoffrey Edwards and Kim Lowell, Faculté de foresterie et de géomatique, Université Laval.

Efficiency and time compared with mechanical and chemical girdling of sugar maple and American beech. Dr. Jean-Marie Binot, École de sciences forestières, Université de Moncton.

The use of radar data in forest fire fighting. Henri-Paul Biron and Luc Pouliot, Québec Weather Centre, Environment Canada, Montréal.

Five-year aerial spray program (1993-1998) against forest pests. Gaston Déry, Société de protection des forêts contre les insectes et maladies, Québec.

The effect of fire on age-class distribution of white and red pine in the Great Lakes - St. Lawrence Forest Region. Luc C. Duchesne and Sylvie Gauthier, Petawawa National Forestry Institute, Ontario.

Canada's forest inventory by forest region. Joe J. Lowe and Stephen Gray, Petawawa National Forestry Institute, Ontario.
Software system for private woodlot management. Justin Manasc and Peter F. Wade, For-éco enr. Knowlton, Québec.

Factors affecting the price of pulpwood from non-industrial private forest of Québec during the last forty years. Solange Nadeau and Luc Bouthillier, Faculté de foresterie et de géomatique, Université Laval.

The wonderful world of forestry. Georges E. Pagé, Ing. For., FOR International Limitée, Montréal, (Québec).

Climatology of Canadian fire weather indices. Luc Pouliot, Québec Weather Centre, Environment Canada, Montréal.

Seedling size and water stress in containerized black spruce. James D. Stewart and Pierre Y. Bernier, Forestry Canada Québec Region.

Effects of prescribed burning intensities and scarification on species diversity in a jack pine forest. Renée Tellier ${ }^{1}$, Luc C. Duchesne ${ }^{1}$ and Jean-Claude Ruel ${ }^{2}$,

'Petawawa National Forestry Institute, Ontario and ${ }^{2}$ Faculté de foresterie et de géomatique, Université Laval.

Effects of prescribed fire intensities and scarification on the survival and health of white and red pine plantation. Renée Tellier ${ }^{1}$, Luc C. Duchesne ${ }^{1}$ and Jean-Claude Ruel $^{2},{ }^{1}$ Petawawa National Forestry Institute, Ontario and ${ }^{2}$ Faculté de foresterie et de géomatique, Université Laval. agents of economic and silviculture development. In this way, forest companies could invest in a profitable way in the development of Québec's forests.

To protect our industry and jobs, the export of roundwood and chips was stopped. By requiring building permits for the construction and enlargement of factories, other factories that would have provided competition were prevented from springing up around existing mills, and the more dynamic mills from developing at the expense of the less productive. Also, this prevented the growth of small production units. By getting directly involved in industrial forestry development, governments diluted the fundamental principle of competition in the name of development and thereby prevented, rather than favoured, development over the medi- um term. The result has been an industry distrustful of government, over-protected and lacking dynamism. New industries have not developed, existing industries have aged and lost their competitiveness. This was the condition of our forest industry when the present recession started - it has neither the will nor the means to extricate itself, without once again turning to government.

It is imperative that the forest industry be deregulated and for governments to withdraw. Besides, government successes are rare in this arena. All unnecessary regulations and restrictions must be abolished. They have no virtue, other than giving a false sense of power to the government officials who administer them. These regulations have proven to be inefficient and they have no practical value.
Restrictions on the export of roundwood and chips must be lifted in order to create a competitive system which will allow the value of standing timber to increase to its real worth. This will trigger the most dynamic and productive mills to grow, and for landowners to reap the maximum value from their forests while providing the funds needed to practise adequate silviculture.

It is impossible to have true competition and the savings gained from it, as well as optimal industrial development, without the means of production being in the hands of the private sector. Therefore, governments must stop investing directly in industry, since experience proves that these investments, made in the name of regional development, generally result in considerable losses. Moreover, they upset the competitive balance among 